\title{
Effects of different barley and oat varieties on methane production, digestibility, and fermentation pattern in vitro
}

\author{
P. Fant, ${ }^{1}$ M. Ramin, ${ }^{1} \odot$ S. Jaakkola, ${ }^{2} \oplus$ A . Grimberg, ${ }^{3} \oplus$ A. S. Carlsson, ${ }^{3} \oplus$ and P. Huhtanen ${ }^{1 *} \odot$ \\ ${ }^{1}$ Department of Agricultural Research for Northern Sweden, Swedish University of Agricultural Sciences, SE-901 83 Umeå, Sweden \\ ${ }^{2}$ Department of Agricultural Sciences, University of Helsinki, PO Box 28, FI-00014 Helsinki, Finland \\ ${ }^{3}$ Department of Plant Breeding, Swedish University of Agricultural Sciences, PO Box 101, SE-230 53 Alnarp, Sweden
}

\section{ABSTRACT}

The objective of this in vitro study was to determine the effects of different barley and oat varieties on $\mathrm{CH}_{4}$ production, digestibility, and rumen fermentation patterns in dairy cows. Our hypothesis was that oat-based diets would decrease $\mathrm{CH}_{4}$ production compared with barley-based diets, and that $\mathrm{CH}_{4}$ production would differ between varieties within grain species. To evaluate this hypothesis, we conducted an in vitro experiment using a fully automated gas production technique, in which the total gas volume was automatically recorded by the system. The experiment consisted of triplicate 48-h incubations with 16 treatments, including 8 different varieties of each grain. The grain varieties were investigated as a mix with an early-cut grass silage (1:1 ratio of grain to silage on a dry matter basis) and mixed with buffered rumen fluid. We estimated predicted in vivo total gas production and $\mathrm{CH}_{4}$ production by applying a set of models to the gas production data obtained by the in vitro system. We also evaluated in vitro digestibility and fermentation characteristics. The variety of grain species did not affect total gas production, $\mathrm{CH}_{4}$ production, or fermentation patterns in vitro. However, in vitro-determined digestibility and $\mathrm{pH}$ were affected by variety of grain species. Grain species affected total gas and $\mathrm{CH}_{4}$ production: compared with barley-based diets, oat-based diets decreased total gas production and $\mathrm{CH}_{4}$ production by 8.2 and $8.9 \%$, respectively, relative to dry matter intake. Grain species did not affect $\mathrm{CH}_{4}$ production relative to in vitro true dry matter digestibility. Oat-based diets decreased digestibility and total volatile fatty acid production, and maintained a higher $\mathrm{pH}$ at $48 \mathrm{~h}$ of incubation compared with barley-based diets. Grain species did not affect fermentation patterns, except for decreased molar proportions of valerate with oat-based diets. These results

Received May 21, 2019.

Accepted October 11, 2019

*Corresponding author: pekka.huhtanen@slu.se suggest that replacing barley with oats in dairy cow diets could decrease enteric $\mathrm{CH}_{4}$ production.

Key words: oats, barley, methane, in vitro

\section{INTRODUCTION}

After water vapor and $\mathrm{CO}_{2}$, methane $\left(\mathrm{CH}_{4}\right)$ is the third most important greenhouse gas contributing to climate change. Compared with $\mathrm{CO}_{2}, \mathrm{CH}_{4}$ is characterized by a greater efficiency in absorbing heat energy and a shorter atmospheric lifetime (12-13 yr), resulting in a global warming potential 28 times greater than $\mathrm{CO}_{2}$ (IPCC, 2014). Ruminant livestock account for approximately $37 \%$ of the global anthropogenic $\mathrm{CH}_{4}$ emissions; a greater part of that originates from enteric fermentation, and a lesser part from manure (FAO, 2006). In addition, enteric $\mathrm{CH}_{4}$ production represents an energy loss to the animal, ranging from 2 to $12 \%$, depending on diet composition and feeding level (Johnson and Johnson, 1995). For these 2 reasons, research aimed at mitigating enteric $\mathrm{CH}_{4}$ emissions from ruminants is very important.

Enteric $\mathrm{CH}_{4}$ production in ruminants is affected by DMI (Johnson and Johnson, 1995), diet composition, chemical composition of feed components, diet digestibility, and individual animal characteristics (Yan et al., 2000). Dietary strategies to decrease $\mathrm{CH}_{4}$ emissions from ruminants have been widely investigated. Many of these involve dietary supplements, such as ionophores (Guan et al., 2006), nitrate (van Zijderveld et al., 2011), secondary plant compounds (Bhatta, 2015), 3-nitroxypropanol (Hristov et al., 2015), and oil supplements (Martin et al., 2008; Beauchemin et al., 2009), which have all been found effective to various degrees. However, for farmers to adopt a $\mathrm{CH}_{4}$-mitigating dietary strategy, the strategy has to be safe, practically applicable at a farm scale, and economically beneficial to the farmer (Hristov et al., 2013), posing problems for the practical application of the strategies above.

Oats (Avena sativa) and barley (Hordeum vulgare) are common grains in the diet of dairy cows, especially 
in the Nordic countries, because yields are relatively high and moderate input is required. Many studies suggest that replacing barley with oats in the diet of dairy cows increases milk yield, decreases milk protein and fat concentrations, and improves the composition of milk fat by increasing the concentration of unsaturated fatty acids (Martin and Thomas, 1988; Ekern et al., 2003; Vanhatalo et al., 2006). In terms of chemical composition, oats express a greater concentration of oil and fiber, with a greater proportion of soluble $\beta$-glucans than barley; barley expresses a higher concentration of starch (Lee et al., 1997). In addition, oats contain several types of antioxidants, such as phenolic compounds and avenanthramides, which are not present in barley (Peterson, 2001). All of these differences in chemical composition between oats and barley could influence enteric $\mathrm{CH}_{4}$ production.

The first objective of this study was to compare oats and barley (and different varieties of each grain) in a grass-silage-based diet in terms of $\mathrm{CH}_{4}$ production, digestibility, and fermentation patterns using an in vitro gas production system. Our hypothesis was that replacing barley with oats would decrease $\mathrm{CH}_{4}$ production, and that $\mathrm{CH}_{4}$ production would differ between varieties of grain species. The second objective was to conduct a regression analysis to explain possible mechanisms of the differences in $\mathrm{CH}_{4}$ production and compare observed responses to the model-predicted responses as a means of evaluating whether oats have a specific $\mathrm{CH}_{4}$ mitigation effect.

\section{MATERIALS AND METHODS}

\section{Grain Samples}

The experimental feed material consisted of 8 varieties of oats and 8 varieties of barley. All grains were hulled and obtained as seed samples from Boreal Plant Breeding Ltd. (Jokioinen, Finland). The grain samples (including hull) were dried at $60^{\circ} \mathrm{C}$ in a forced-air oven for $48 \mathrm{~h}$ and milled through a 1.0-mm screen using a laboratory mill (Retsch SM2000; Rheinische, Haan, Germany).

\section{Experimental Design and Treatments}

The in vitro gas production experiment consisted of triplicate runs of $48 \mathrm{~h}$ in vitro. Each run included 36 samples: 16 treatments $\times 2$ replicates and 4 blank samples containing only buffered rumen fluid. Feed samples and buffered rumen fluid were mixed in serum bottles (250 mL; Schott, Mainz, Germany) and incubated in a water bath. Before each run, serum bottles were ran- domized to the 36 positions in the water bath so that each treatment had a different position during each run. The ratio of incubated grain to silage was $1: 1$ on a DM basis; each treatment contained $500 \mathrm{mg}$ of barley or oats, and $500 \mathrm{mg}$ of silage. The silage was early-cut silage harvested from primary growth of a third-year lay dominated by timothy (Phleum pratense). The fields were fertilized with $70 \mathrm{~kg}$ of $\mathrm{N} / \mathrm{ha}$ in the spring. The silage samples were treated in the same way as the grain samples.

\section{In Vitro Incubations}

All experimental procedures were approved by the Umeå Ethics Committee for Animal Research, Sweden, and by the National Animal Ethics Committee, Finland. Rumen fluid was collected approximately 2 $\mathrm{h}$ after morning feeding from 2 fistulated Nordic Red dairy cows in late lactation that were fed a TMR of grass silage and concentrate $(600: 400 \mathrm{~g} / \mathrm{kg}$ on a DM basis) ad libitum. The concentrate consisted of rolled barley and rape seed meal (800:200 g/kg on a DM basis). The rumen fluid was kept in 2 steel thermoses that had been prewarmed and flushed with $\mathrm{CO}_{2}$ to ensure an anaerobic environment. The $\mathrm{pH}$ value of the rumen fluid (mean 6.27, standard deviation 0.12) was recorded (744 pH Meter; Metrohm Ltd., Herisau, Switzerland) before it was filtered through 4 layers of cheesecloth into a measuring cylinder continuously flushed with $\mathrm{CO}_{2}$. A total of $483 \mathrm{~mL}$ of rumen fluid was transferred through a funnel into another measuring cylinder containing $483 \mathrm{~mL}$ of buffer solution mixed with microand macrominerals as described by Menke (1988), at $39^{\circ} \mathrm{C}$ under constant stirring and continuous flushing with $\mathrm{CO}_{2}$. The buffered rumen fluid was supplemented with peptone (pancreatic digested casein; Merck, Darmstadt, Germany). Feed samples were incubated in $60 \mathrm{~mL}$ of buffered rumen fluid and placed in a water bath at $39^{\circ} \mathrm{C}$ with continuous agitation for $48 \mathrm{~h}$. The in vitro gas production experiment was conducted using a fully automated gas production technique described by Cone et al. (1996), in which the total gas volume is automatically recorded at 0.2 -h intervals and corrected for the normal atmospheric pressure $(101.3 \mathrm{kPa})$.

\section{Gas Sampling}

To predict $\mathrm{CH}_{4}$ production in vivo based on the data from the in vitro system, we used the method of Ramin and Huhtanen (2012). Gas sampling was performed at $2,4,8,24,32$, and $48 \mathrm{~h}$ of incubation by drawing a gas sample from each bottle in a gas-tight syringe (Hamilton, Bonaduz, Switzerland) through the rubber suba 
seal. A sample size of $0.2 \mathrm{~mL}$ of gas was injected into a gas chromatograph (Varian Star 3400 CX FID Gas Chromatograph; Varian Inc., Palo Alto, CA), equipped with a thermal conductivity detector. A standard mixture of $\mathrm{CO}_{2}(900 \mathrm{mmol} / \mathrm{mol})$ and $\mathrm{CH}_{4}(100 \mathrm{mmol} / \mathrm{mol})$ was used as a calibration gas (AGA Gas AB, Sundbyberg, Sweden), and gas sample peaks were recognized by comparison with the standard gas. The duration of the gas sampling process was approximately the same as that of the incubation process (35-45 min), ensuring an equal fermentation time in all bottles.

\section{VFA, pH Measurements, and Digestibility Analysis}

Each bottle was sampled for VFA analysis at $48 \mathrm{~h}$ of incubation by drawing a sample of $0.3 \mathrm{~mL}$ fluid residue using a liquid syringe. The fluid samples were pooled within treatment and run and stored in Eppendorf tubes at $-18^{\circ} \mathrm{C}$ until further analysis. Concentration of VFA was determined by liquid chromatographic analysis using a Waters Acquity ultra-performance liquid chromatography apparatus (Waters, Milford, MA), as described in detail by Puhakka et al. (2016). The concentration of total VFA $(\mathrm{mmol} / \mathrm{L})$ was calculated as the difference between total VFA concentration in the sample and average total VFA concentration in the blanks. Total VFA production (mmol) was calculated by multiplying the difference in VFA concentration (sample - blank) by the sample volume $(60 \mathrm{~mL})$. The $\mathrm{pH}$ of each bottle at $48 \mathrm{~h}$ of incubation was also determined (744 pH Meter; Metrohm Ltd.). The in vitro digestibility was determined as true DM digestibility (TDMD). Sampling for TDMD was performed at 48 $\mathrm{h}$ of incubation by transferring the feed sample residue from each bottle into a preweighed polyester bag with a pore size of $11 \mu \mathrm{m}$. All excess liquid was carefully pressed out through the pores of the bag. The nylon bags were sealed and stored at $-18^{\circ} \mathrm{C}$ until further analysis. On the day of analysis, the sample bags were thawed and boiled in an NDF solution for $1 \mathrm{~h}$ with added heat-stable $\alpha$-amylase and sodium sulfite. Sample bags were dried at $60^{\circ} \mathrm{C}$ for $48 \mathrm{~h}$ before weighing.

\section{Chemical Analysis}

Dry matter concentration was determined by drying the grain (including the hull) and silage samples at $105^{\circ} \mathrm{C}$ for $16 \mathrm{~h}$. Ash concentration was determined by incinerating the samples at $500^{\circ} \mathrm{C}$ for $4 \mathrm{~h}$ (AOAC International, 2012) and $\mathrm{OM}$ concentration was calculated as the difference between 1,000 and the ash concentration. Nitrogen concentration was determined using the Kjeldahl method (AOAC International, 2012) and a
Tecator digestion system (Tecator Digestion Auto and Tecator Scrubber; Foss Analytical, Hillerød, Denmark) and a distillation and titration apparatus (Kjeltec Auto 2300; Foss Analytical). We calculated CP concentration by multiplying the $\mathrm{N}$ concentration by 6.25 . We determined crude fat concentration by ether extraction and $\mathrm{HCl}$ hydrolysis (Foss Soxtec 8000 extraction unit, SoxCap 2047 hydrolysis unit; Foss Analytical). The NDF concentration was determined using the method described by Van Soest et al. (1991), using a 1020 hot and 1021 cold extractor (Tecator Fibertec System; Foss Analytical) with addition of heat-stable $\alpha$-amylase and sodium sulfite. The NDF concentration was expressed free of residual ash (aNDF). Indigestible NDF (iNDF) concentration was determined by applying a 288-h in situ incubation as described by Krizsan et al. (2015), using polyester bags with a pore size of $6 \mu \mathrm{m}$ and a pore area equal to $5 \%$ of the total surface area. Sample bags were incubated in 2 lactating Ayrshire dairy cows fitted with a rumen fistula at the research farm at the Department of Agricultural Sciences at the University of Helsinki, Finland. The cows were fed a diet based on grass silage and concentrate (60:40 on a DM basis). Indigestible NDF was expressed inclusive of residual ash. Frozen silage samples were thawed and pressed before analysis. Ammonia- $\mathrm{N}$ was analyzed by direct distillation after adding $\mathrm{MgO}$ using a Kjeltec 2100 Distillation Unit (Foss Analytical). We analyzed VFA and lactic acid according to the method of Ericson and André (2010).

\section{Predicted In Vivo Methane Production}

We calculated the cumulative $\mathrm{CH}_{4}$ production $(\mathrm{mL})$ at each time point $(0.2 \mathrm{~h})$ according to the following equation:

$$
\begin{gathered}
\mathrm{V}_{\mathrm{CH} 4}(\mathrm{~mL})=\mathrm{V}_{\mathrm{HS}}(\mathrm{mL}) \times \mathrm{CH}_{4}(\mathrm{~mL} / \mathrm{mL}) \\
+\mathrm{V}_{\mathrm{GP}}(\mathrm{mL}) \times \mathrm{A} \times \mathrm{CH}_{4}(\mathrm{~mL} / \mathrm{mL}),
\end{gathered}
$$

where $\mathrm{V}_{\mathrm{CH} 4}$ was the total $\mathrm{CH}_{4}$ production at each time point; $\mathrm{V}_{\mathrm{HS}}$ was the headspace volume; $\mathrm{CH}_{4}$ was the $\mathrm{CH}_{4}$ concentration in the headspace; $\mathrm{V}_{\mathrm{GP}}$ was the gas production volume; and coefficient $\mathrm{A}$ was the ratio of $\mathrm{CH}_{4}$ concentration in the outflow gas to the headspace. Coefficient A (0.55) was predicted using a mechanistic model described by Ramin and Huhtanen (2012).

Methane concentration at 0.2 -h time intervals was estimated by fitting a logarithmic regression of measured $\mathrm{CH}_{4}$ at 6 time points, as described by Ramin and Huhtanen (2012). Methane production (mL) at each time point (0.2) was calculated as total gas production $\times$ calculated $\mathrm{CH}_{4}$ concentration. The kinetic param- 
eters of total gas production and $\mathrm{CH}_{4}$ production at each time point $(0.2)$ were predicted separately by fitting the data to the 2-pool Gompertz model described by Schofield et al. (1994), using the NLIN procedure in SAS version 9.4 (SAS Institute Inc., Cary, NC) according to the following equation:

$$
\begin{gathered}
\mathrm{V}_{\mathrm{t}}=\mathrm{V}_{1} \times \operatorname{Exp}\left\{-\operatorname{Exp}\left[1-\mathrm{k}_{1} \times\left(\mathrm{t}-\mathrm{L}_{1}\right)\right]\right\} \\
+\mathrm{V}_{2} \times \operatorname{Exp}\left\{-\operatorname{Exp}\left[1-\mathrm{k}_{2} \times\left(\mathrm{t}-\mathrm{L}_{2}\right)\right]\right\},
\end{gathered}
$$

where $\mathrm{V}_{\mathrm{t}}$ is measured total gas or $\mathrm{CH}_{4}$ volume at time $\mathrm{t} ; \mathrm{V}_{1}, \mathrm{k}_{1}$, and $\mathrm{L}_{1}$ are asymptotic cumulative gas production $(\mathrm{mL} / \mathrm{g}$ of $\mathrm{DM})$, rate $(1 / \mathrm{h})$, and lag $(\mathrm{h})$ parameters, respectively, for the first pool (rapid); $\mathrm{V}_{2}, \mathrm{k}_{2}$, and $\mathrm{L}_{2}$ are the corresponding parameters for the second pool (slow); and $\mathrm{t}$ is incubation time.

The parameters were subjected to a dynamic, mechanistic 2-compartment rumen model as described by Huhtanen et al. (2008), with modifications as described by Ramin and Huhtanen (2012). The model was used to predict the proportion of asymptotic $\mathrm{CH}_{4}$ production at infinitive time that would be produced during the residence of feed in the rumen and the simulations were performed using POWERSIM version 2.5 (Powersim Software, Bergen, Norway) with a retention time of 50 $\mathrm{h}$, which represented the maintenance level of intake. Predicted in vivo $\mathrm{CH}_{4}$ production $(\mathrm{mL} / \mathrm{g}$ of $\mathrm{DM})$ was calculated as $\mathrm{CH}_{4}=$ proportion $\times$ asymptotic $\mathrm{CH}_{4}$ production $(\mathrm{mL} / \mathrm{g}$ of $\mathrm{DM})$ and expressed it as grams per kilogram of DM, calculated as follows:

$$
\begin{aligned}
\mathrm{CH}_{4}(\mathrm{~g} / \mathrm{kg} \text { of DM}) & =\mathrm{CH}_{4}(\mathrm{~mL} / \mathrm{g} \text { of DM }) / \\
22.4(\mathrm{~L} / \mathrm{mol}) & \times 16.04(\mathrm{~g} / \mathrm{mol})
\end{aligned}
$$

where 22.4 is the gas volume and 16.04 is the molar mass of $\mathrm{CH}_{4}$.

\section{Stoichiometrically Predicted Methane Production}

Stoichiometrically predicted $\mathrm{CH}_{4}\left(\mathbf{C H}_{4} \mathbf{V F A}\right)$ production was calculated using the amounts of acetate, propionate, and butyrate produced in vitro according to the following equation (Wolin, 1960):

$$
\begin{gathered}
\mathrm{CH}_{4} \mathrm{VFA}(\mathrm{mL})=22.4 \times(0.50 \times \mathrm{AA}-0.25 \\
\times \mathrm{PA}+0.50 \times \mathrm{BA}),
\end{gathered}
$$

where AA, PA, and BA are the total amounts (mmol) of acetate, propionate, and butyrate, respectively, in the feed samples at $48 \mathrm{~h}$ of incubation and 22.4 is gas volume (L/mol of gas). The VFA data were corrected for blanks.

\section{Predicted Methane Production Using Mechanistic and Empirical Equations}

The Nordic dairy cow model Karoline is a mechanistic dairy cow model described by Danfær et al. (2006). In this study, we used the sub-model predicting $\mathrm{CH}_{4}$ production, recently revised by Huhtanen et al. (2015), to predict methane. The Karoline model requires a set of input variables, such as the chemical composition parameters of the feedstuff and the kinetic digestion rates for specific feed fractions. If required input variables were not analyzed, they were estimated or derived from feed tables. For grains and silage, potentially digestible NDF was calculated as the difference between aNDF and iNDF. The sugar concentration of oats $(18 \mathrm{~g} / \mathrm{kg}$ of $\mathrm{DM})$ and barley $(20 \mathrm{~g} / \mathrm{kg}$ of DM) was derived from national feed tables (LUKE, 2019). Starch concentration for each individual grain variety was calculated as OM - CP - crude fat - aNDF - sugar. The grain protein fractions of amino nitrogen, peptide nitrogen, soluble protein nitrogen, insoluble protein, and indigestible protein for grains were derived from the Cornell Net Carbohydrate and Protein System feed table (Tylutki et al., 2008). Values for the digestion rate of NDF were set at 0.050 and $0.066 / \mathrm{h}$ for oats and barley, respectively. For the digestion rate of starch, we used a value of $0.2 / \mathrm{h}$ for both grains. The digestion rate of insoluble protein was set at 0.09 and $0.11 / \mathrm{h}$ for oats and barley, respectively. Silage protein fractions and digestion rates were based on the Cornell Net Carbohydrate and Protein System feed table (Tylutki et al., 2008). The Karoline simulations were based on a $60-\mathrm{kg}$ sheep fed at maintenance level of intake (1 kg of DMI/d).

We also predicted $\mathrm{CH}_{4}$ production using an empirical equation developed and described by Ramin and Huhtanen (2013), which is based on feed intake and the chemical composition of the feed, as follows:

$$
\begin{gathered}
\mathrm{CH}_{4}(\mathrm{~L} / \mathrm{kg} \text { of DMI })=5-0.35 \times \mathrm{DMIBW}+0.031 \\
\times \mathrm{OMD}_{\mathrm{m}}- \\
0.043 \times \mathrm{EE}+0.018 \times \mathrm{NDF} \\
+0.018 \times \mathrm{NFC}
\end{gathered}
$$

where DMIBW is DMI per unit of $\mathrm{BW}(\mathrm{g} / \mathrm{kg}) ; \mathrm{OMD}_{\mathrm{m}}$ is $\mathrm{OM}$ digestibility at a maintenance level of feed intake $(\mathrm{g} / \mathrm{kg})$; $\mathrm{EE}$ is ether extract $(\mathrm{g} / \mathrm{kg}$ of $\mathrm{DM})$; NDF is given in grams per kilogram of DM; and NFC $(\mathrm{g} / \mathrm{kg}$ of $\mathrm{DM})$ was calculated as $\mathrm{OM}-\mathrm{CP}-\mathrm{NDF}$ - crude fat (NRC, 2001). Empirical $\mathrm{CH}_{4}$ production $(\mathrm{g} / \mathrm{kg}$ of $\mathrm{DM})$ was calculated as

$$
\begin{gathered}
\mathrm{CH}_{4}(\mathrm{~g} / \mathrm{kg} \text { of } \mathrm{DM})=\mathrm{CH}_{4}(\mathrm{~L} / \mathrm{kg} \text { of DMI }) \\
\times 1(\mathrm{~L}) / 22.4(\mathrm{~L} / \mathrm{mol}) \times 16.04(\mathrm{~g} / \mathrm{mol}),
\end{gathered}
$$


where 22.4 is the gas volume and 16.04 is the molar mass of $\mathrm{CH}_{4}$.

\section{Statistical Analysis}

All statistical analyses were performed using SAS version 9.4 (SAS Institute Inc.). Data for total gas and $\mathrm{CH}_{4}$ production parameters $(\mathrm{g} / \mathrm{kg}$ of DM), TDMD $(\mathrm{g} /$ $\mathrm{kg}$ of $\mathrm{DM}$ ), and $\mathrm{pH}$ values were subjected to ANOVA using the MIXED procedure in SAS according to the following model:

$$
\mathrm{Y}_{\mathrm{ijkl}}=\mu+\mathrm{G}_{\mathrm{i}}+\mathrm{V}(\mathrm{G})_{\mathrm{ij}}+\mathrm{R}_{\mathrm{k}}+\mathrm{b}_{\mathrm{l}}+\varepsilon_{\mathrm{ijkl}},
$$

where $Y_{\mathrm{ijkl}}$ is the observation; $\mu$ is the overall mean; $\mathrm{G}_{\mathrm{i}}$ is the effect of grain $(\mathrm{i}=2) ; \mathrm{V}(\mathrm{G})_{\mathrm{ij}}$ is the effect of variety within grain $(j=16) ; R_{k}$ is the effect of the run $(\mathrm{k}=3) ; \mathrm{b}_{\mathrm{l}}$ is the random effect of bottle (position in bath); and $\varepsilon_{\mathrm{ijkl}}$ is the random error term. Because the samples for $\mathrm{CH}_{4} \mathrm{VFA}$ (g/kg of DM), total VFA production (mmol), and molar proportions of VFA (mmol/ mol) for each run were pooled within treatment, these data were subjected to ANOVA by a different model using the MIXED procedure in SAS:

$$
Y_{i j k}=\mu+G_{i}+V(G)_{i j}+R_{k}+\varepsilon_{i j k},
$$

where $Y_{i j k}$ is the observation; $\mu$ is the overall mean; $G_{i}$ is the effect of grain; $V(G)_{i j}$ is the effect of variety within grain; $R_{k}$ is the random effect of the run; and $\varepsilon_{\mathrm{ijk}}$ is the random error term. We tested the data used in both models using the Shapiro-Wilk test for normality and homoscedasticity of residuals. The results were considered statistically significant when $P<0.05$, and highly significant when $P<0.01$. We adjusted $P$ values for multiple comparisons of variety within grain using Tukey's test. To investigate possible relationships between predicted in vivo $\mathrm{CH}_{4}$ and grain composition (TDMD, OM, CP, aNDF, iNDF, and crude fat) a regression analysis was performed by using the REG procedure in SAS. To investigate possible interactions between grain species and grain composition on predicted in vivo $\mathrm{CH}_{4}$ production, we performed a regression analysis using the GLM procedure in SAS.

\section{RESULTS}

\section{Chemical Composition of Feeds}

The chemical composition of the oat and barley varieties and the means and standard deviations within grain species are presented in Table 1 . The most pro- nounced differences between the oat and barley varieties were higher concentration of aNDF, iNDF, and crude fat in the oat varieties compared with the barley varieties. The silage had a DM concentration of 285 $\mathrm{g} / \mathrm{kg}$ of fresh weight. The concentrations of OM, CP, aNDF, and iNDF were 938, 157, 611, and $102 \mathrm{~g} / \mathrm{kg}$ of DM, respectively. The fermentation quality of the silage was good, in that it had low concentrations of ammonia $\mathrm{N}(45.0 \mathrm{~g} / \mathrm{kg}$ of $\mathrm{N})$. Concentrations of lactic acid, acetic acid, propionic acid, and butyric acid were $99.6,21.6,1.06$, and $0.27 \mathrm{~g} / \mathrm{kg}$ of DM, respectively.

\section{Total Gas and Methane Production}

The findings for total gas and predicted in vivo $\mathrm{CH}_{4}$ production measurements are presented in Table 2. Total gas production and predicted in vivo $\mathrm{CH}_{4}$ production were 8.2 and $8.9 \%$ lower $(P<0.01)$, respectively, in oat-based diets than in barley-based diets. The variety of grain species did not affect total gas or predicted in vivo $\mathrm{CH}_{4}$ production. The mechanistic and empirical $\mathrm{CH}_{4}$ predictions are illustrated in Figure 1. Both models expressed a good relationship to predicted in vivo $\mathrm{CH}_{4}$; root mean square errors were 0.80 and 0.78 for the mechanistic and empirical models, respectively. Although $\mathrm{R}^{2}$ values were not very high (0.67 and 0.68 for the mechanistic and empirical models, respectively), relative prediction errors were 3.6 and $3.5 \%$, respectively, of the observed mean.

\section{Relationships Between Predicted In Vivo Methane Production and Grain Composition Parameters}

The results from simple and multiple regression analysis of predicted in vivo $\mathrm{CH}_{4}$ production and grain parameters are presented in Table 3 . The best predictor of $\mathrm{CH}_{4}$ production was TDMD. Among grain composition parameters, iNDF concentration was the best predictor of $\mathrm{CH}_{4}$ production. The mean response in $\mathrm{CH}_{4}$ production to increased iNDF concentration was $-0.020 \mathrm{~g} / \mathrm{kg}$ of DM per $1 \mathrm{~g} / \mathrm{kg}$ of DM in iNDF. Grain aNDF concentration was only slightly less associated with $\mathrm{CH}_{4}$ production than iNDF concentration. Using crude fat concentration as a predictor instead of iNDF or aNDF increased the prediction error slightly. However, the mean response in $\mathrm{CH}_{4}$ production to crude fat $(-0.087 \mathrm{~g} / \mathrm{kg}$ of DM per $1 \mathrm{~g} / \mathrm{kg}$ of DM crude fat) was greater than that to iNDF or aNDF. Grain CP concentration did not affect $\mathrm{CH}_{4}$ production. When the data were classified according to grain species $(n=8)$, we found no interactions between grain type and grain parameters $(P>0.54)$ with respect to predicted in 
Table 1. Chemical composition of oat and barley varieties incubated in the in vitro gas production experiment

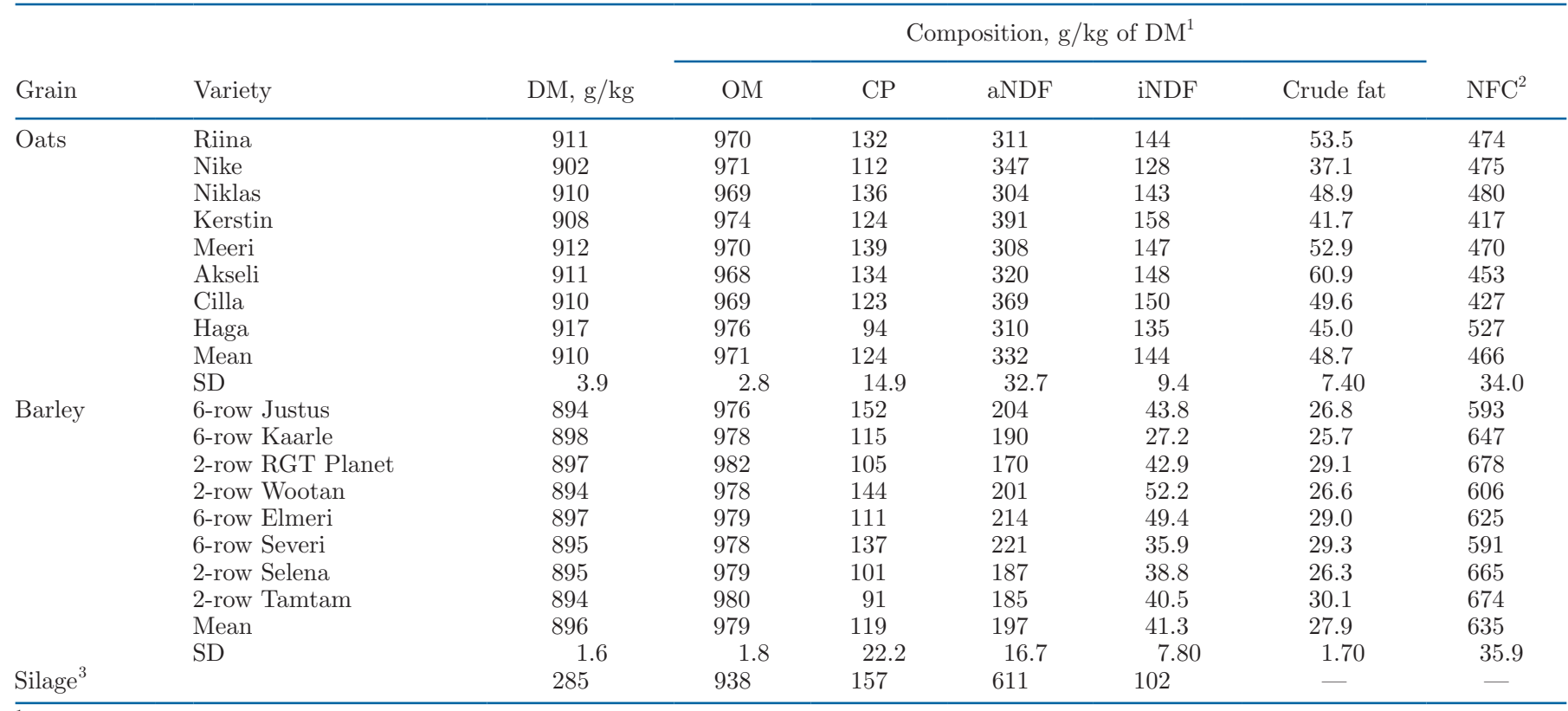

${ }^{1}$ aNDF $=$ NDF free of residual ash; iNDF $=$ indigestible NDF.

${ }^{2} \mathrm{NFC}$ not analyzed; calculated as OM - CP - aNDF - crude fat (NRC, 2001).

${ }^{3}$ Concentration of ammonia $\mathrm{N}$ was $45.0 \mathrm{~g} / \mathrm{kg}$ of $\mathrm{N}$, lactic acid $99.6 \mathrm{~g} / \mathrm{kg}$ of DM, acetic acid $21.6 \mathrm{~g} / \mathrm{kg}$ of DM, propionic acid $1.06 \mathrm{~g} / \mathrm{kg}$ of DM, and butyric acid $0.27 \mathrm{~g} / \mathrm{kg}$ of DM.

vivo $\mathrm{CH}_{4}$ production. Bivariate models did not improve predictions because of collinearity between variables (models not shown).

\section{Digestibility and Fermentation Pattern In Vitro}

Results for digestibility expressed as TDMD, pH at $48 \mathrm{~h}$ of incubation, and VFA production parameters are presented in Table 4. True DMD decreased by $7.0 \%$ in oat-based diets compared with barley-based diets $(P<0.01)$ and variety of grain species also affected TDMD $(P=0.04)$. We observed a negative relationship between iNDF concentration and TDMD among the varieties of oats and barley (Figure 2). Oat-based diets increased the $\mathrm{pH}$ value at $48 \mathrm{~h}$ of incubation compared with barley-based diets $(P<0.01)$, whereas barleybased diets expressed a higher production of total VFA than oat-based diets $(P<0.01)$. In addition, variety of grain affected $\mathrm{pH}$ at $48 \mathrm{~h}$ of incubation $(P<0.01)$, but when $P$-values were adjusted for multiple testing, we observed differences only between some of the barley varieties, ranging from 0.06 to $0.10 \mathrm{pH}$ units. Grain and variety of grain did not affect the molar proportions of VFA, except for a significantly greater proportion of

Table 2. Effects of grain species and variety within grain species on predicted in vivo total gas and methane production

\begin{tabular}{|c|c|c|c|c|c|c|}
\hline \multirow[b]{2}{*}{ Item } & \multirow[b]{2}{*}{ Oats } & \multirow[b]{2}{*}{ Barley } & \multicolumn{2}{|c|}{ SEM } & \multicolumn{2}{|c|}{$P$-value } \\
\hline & & & Oats & Barley & Grain & Variety \\
\hline Asymptotic gas & 160 & 173 & 3.4 & 3.2 & $<0.01$ & 0.23 \\
\hline Predicted gas ${ }^{1}$ & 145 & 158 & 2.9 & 2.7 & $<0.01$ & 0.30 \\
\hline \multicolumn{7}{|l|}{$\mathrm{CH}_{4}$} \\
\hline Asymptotic $\mathrm{CH}_{4}, \mathrm{~g} / \mathrm{kg}$ of DM & 25.6 & 28.2 & 0.41 & 0.39 & $<0.01$ & 0.21 \\
\hline Predicted in vivo $\mathrm{CH}_{4}, \mathrm{~g} / \mathrm{kg}$ of TDMD ${ }^{2}$ & 27.0 & 27.5 & 0.37 & 0.35 & 0.26 & 0.36 \\
\hline $\mathrm{CH}_{4} /$ total gas, ${ }^{3} \%$ & 14.9 & 15.1 & 0.22 & 0.21 & 0.50 & 0.67 \\
\hline
\end{tabular}

${ }^{1}$ Predicted in vivo total gas and $\mathrm{CH}_{4}$ production based on observed values corrected for a mean retention time of $50 \mathrm{~h}$.

${ }^{2} \mathrm{TDMD}=$ true $\mathrm{DM}$ digestibility determined at $48 \mathrm{~h}$ of incubation in vitro.

${ }^{3}$ Predicted in vivo $\mathrm{CH}_{4}(\mathrm{~g} / \mathrm{kg}$ of DM) divided by predicted total gas $(\mathrm{g} / \mathrm{kg}$ of DM). 
Table 3. Relationships between grain variables $(\mathrm{g} / \mathrm{kg}$ of $\mathrm{DM})$ and predicted in vivo $\mathrm{CH}_{4}$ production $(\mathrm{g} / \mathrm{kg}$ of $\mathrm{DM} ; \mathrm{n}=16)$

\begin{tabular}{lcccccrrr}
\hline Item $^{1}$ & Intercept & SE & $P$-value & Slope & SE & $P$-value & RMSE $^{2}$ & Adjusted R $^{2}$ \\
\hline TDMD & -6.9 & 4.97 & 0.19 & 0.036 & 0.006 & $<0.01$ & 0.74 \\
aNDF & 26.2 & 0.81 & $<0.01$ & -0.014 & 0.003 & $<0.01$ & 0.85 \\
iNDF & 24.3 & 0.43 & $<0.01$ & -0.020 & 0.004 & $<0.01$ & 0.84 & 0.589 \\
Crude fat & 25.8 & 0.75 & $<0.01$ & -0.087 & 0.019 & $<0.01$ & 0.87 & 0.602 \\
\hline
\end{tabular}

${ }^{1} \mathrm{aNDF}=\mathrm{NDF}$ free of residual ash; iNDF $=$ indigestible NDF; TDMD $=$ true DM digestibility.

${ }^{2} \mathrm{RMSE}=$ root mean square error.

valerate in barley-based diets compared with oat-based diets.

\section{DISCUSSION}

\section{Chemical Composition of Feeds}

Oat grain displays a greater proportion of hull than barley grain, accounting for approximately $25 \%$ in oats and $13 \%$ in barley, whereas barley displays a greater proportion of endosperm than oats, accounting for approximately $76 \%$ in barley and $63 \%$ in oats (Evers and Millar, 2002). The greater proportion of fibrous hull in oats is reflected in the higher aNDF concentration compared with barley. The greatest difference in aNDF concentration observed in this study was $221 \mathrm{~g} / \mathrm{kg}$ of
DM between the oat variety Kerstin and the barley variety RGT Planet. The endosperm serves as a storage compartment for most of the starch in cereal grains, and the difference in endosperm proportion is reflected in the greater concentration of starch in barley than in oats (Evers and Millar, 2002). We did not analyze starch concentration in this study, but the calculated values (OM - CP - crude fat - aNDF - sugar) of 630 and $450 \mathrm{~g} / \mathrm{kg}$ of DM in barley and oats, respectively, were within the normal ranges of 510 to $640 \mathrm{~g} / \mathrm{kg}$ of DM (barley) and 400 to $500 \mathrm{~g} / \mathrm{kg}$ of DM (oats) reported by Holtekjølen et al. (2006) and Sayer and White (2011).

Oats are known to have a higher oil concentration than barley; most of the oil $(96 \%)$ is found in the groat, and the rest is found in the hull (Bryngelsson et al., 2002). The groat oil is largely found in the endosperm

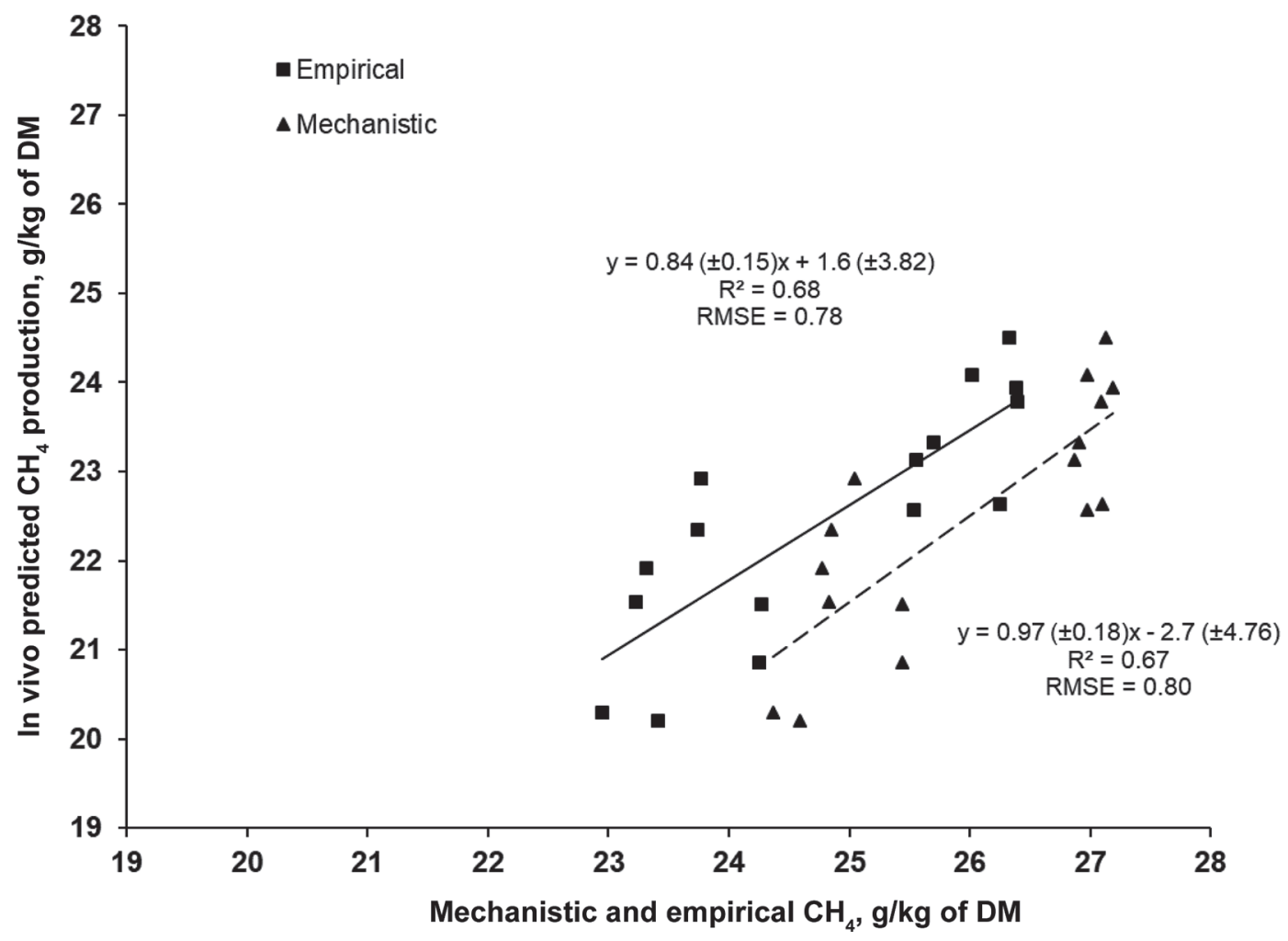

Figure 1. The relationship between predicted in vivo $\mathrm{CH}_{4}$ production and $\mathrm{CH}_{4}$ production predicted by the mechanistic Nordic dairy cow model Karoline and the empirical equation developed by Ramin and Huhtanen (2013). RMSE = root mean square error. 
Table 4. Effects of grain species and variety within grain species on in vitro TDMD, pH, total VFA production, VFA molar proportions, and stoichiometrically predicted $\mathrm{CH}_{4}$ production at $48 \mathrm{~h}$ of incubation in vitro

\begin{tabular}{|c|c|c|c|c|c|c|}
\hline \multirow[b]{2}{*}{ Item } & \multirow[b]{2}{*}{ Oats } & \multirow[b]{2}{*}{ Barley } & \multicolumn{2}{|c|}{ SEM } & \multicolumn{2}{|c|}{$P$-value } \\
\hline & & & Oats & Barley & Grain & Variety \\
\hline TDMD ${ }^{1} \mathrm{~g} / \mathrm{kg}$ of DM & 795 & 855 & 1.9 & 1.8 & $<0.01$ & 0.04 \\
\hline $\mathrm{pH}$ & 6.26 & 6.11 & 0.005 & 0.005 & $<0.01$ & $<0.01$ \\
\hline Total VFA production, $\mathrm{mmol} / \mathrm{g}$ of $\mathrm{DM}$ & 3.30 & 3.68 & 0.11 & 0.11 & $<0.01$ & 0.55 \\
\hline \multicolumn{7}{|l|}{ VFA molar proportions, $\mathrm{mmol} / \mathrm{mol}$} \\
\hline Acetate & 630 & 628 & 4.4 & 4.4 & 0.65 & 0.51 \\
\hline Isobutyrate & 3.9 & 5.0 & 0.49 & 0.49 & 0.12 & 0.59 \\
\hline Valerate & 12.4 & 14.3 & 0.74 & 0.74 & 0.03 & 0.34 \\
\hline Isovalerate & 1.1 & 2.7 & 0.57 & 0.57 & 0.08 & 0.56 \\
\hline $\mathrm{CH}_{4} \mathrm{VFA},{ }^{2} \mathrm{~mL}$ & 24.6 & 27.3 & 0.79 & 0.79 & $<0.01$ & 0.44 \\
\hline
\end{tabular}

${ }^{1} \mathrm{TDMD}=$ true DM digestibility determined at $48 \mathrm{~h}$ of incubation in vitro.

${ }^{2} \mathrm{CH}_{4} \mathrm{VFA}=$ stoichiometrically predicted $\mathrm{CH}_{4}$ production using the amount of acetate, propionate, and butyrate produced in vitro (Wolin, 1960).

(86-90\%), and smaller proportions are found in the scutellum and embryo (Banaś et al., 2007). Compared with the reported total variation in oil concentration among hulled oat varieties (30 to $110 \mathrm{~g} / \mathrm{kg}$ of DM; Zhou et al., 1999), the varieties evaluated in this study were in the lower range $(37-61 \mathrm{~g} / \mathrm{kg}$ of $\mathrm{DM})$; high-oil oat varieties in the upper range were not represented. The variations in crude fat concentration among the barley varieties were smaller $(26-30 \mathrm{~g} / \mathrm{kg}$ of $\mathrm{DM})$ than among the oat varieties, but well in line with the reported variations (19-41 g/kg of DM; Welch, 1978).

The variations in $\mathrm{CP}$ concentration among the barley varieties found in this study (91-152 g/ $\mathrm{kg}$ of DM) were well in line with reported variations (99-187 g/ $\mathrm{kg}$ of DM; Welch, 1978). However, the variations in $\mathrm{CP}$ concentration among the oat varieties were smaller than among barley varieties (94-139 g/ $\mathrm{kg}$ of DM) and compared with reported variations $(112-160 \mathrm{~g} / \mathrm{kg}$ of DM; Welch and McConnell, 2001).

\section{Method}

It is difficult to create an in vitro environment exactly similar to the in vivo environment, and our in vitro gas production system had some limitations. There is no absorption of VFA and no continuous intake of feedstuff during incubation. However, the prediction error of $\mathrm{CH}_{4}$ production was relatively small $(9.5 \%$ of observed mean) in the study by Danielsson et al. (2017), in which predicted in vivo $\mathrm{CH}_{4}$ values obtained from the in vitro gas production system were compared with observed values from in vivo studies that measured $\mathrm{CH}_{4}$ using respiration chambers or the GreenFeed system (C-Lock Inc., Rapid City, SD). The estimated proportion of gross energy (Volden, 2011) lost as $\mathrm{CH}_{4}$ ranged between 6.1 and $7.4 \%$, close to the predicted values of
Ramin and Huhtanen (2012) at a maintenance level of feed intake using the same in vitro gas production approach as used in the present study. In addition, these values were also well in line with values obtained in vivo on grass silage-based diets (Yan et al., 2000).

Because the proportion of grain was only $50 \%$ (on a DM basis) of the incubated feed mixture in this study, the observed decrease in TDMD of 7 percentage units for the oat-based diets compared with the barley-based diets fell well in line with the values in national feed tables, which reported a 10- to 12-percentage-unit difference in digestibility between oats and barley (LUKE, 2019). In addition, the $\mathrm{pH}$ levels observed in this experiment (6.11 and 6.26 for barley and oats, respectively) at $48 \mathrm{~h}$ of incubation may be regarded as in the normal range, indicating that the buffered mineral solution used in vitro was able to imitate the effect of saliva excreted in vivo. Contrary to the findings of this study, Vanhatalo et al. (2006) reported no differences in $\mathrm{pH}$ between oats and barley when compared in vivo on a grass-silage-based diet. This inconsistency may be explained by the differences between the in vitro and in vivo environments. The variation in $\mathrm{pH}$ at $48 \mathrm{~h}$ of incubation expressed a close relationship $\left(\mathrm{R}^{2}=0.90\right)$ with the variation in TDMD among the different grain varieties, whereas total VFA production was less associated $\left(\mathrm{R}^{2}=0.38\right)$ with the variation in $\mathrm{pH}$.

The observed decrease in total VFA production for oat-based diets compared with barley-based diets was consistent with the results of Vanhatalo et al. (2006) and can be explained by the lower digestibility of oats compared with barley. However, the decrease in total VFA production was $10 \%$, whereas the decrease in TDMD was only $7 \%$, indicating that additional factors lowered total VFA production. Because dietary fatty acids are not fermented in the rumen and do not con- 


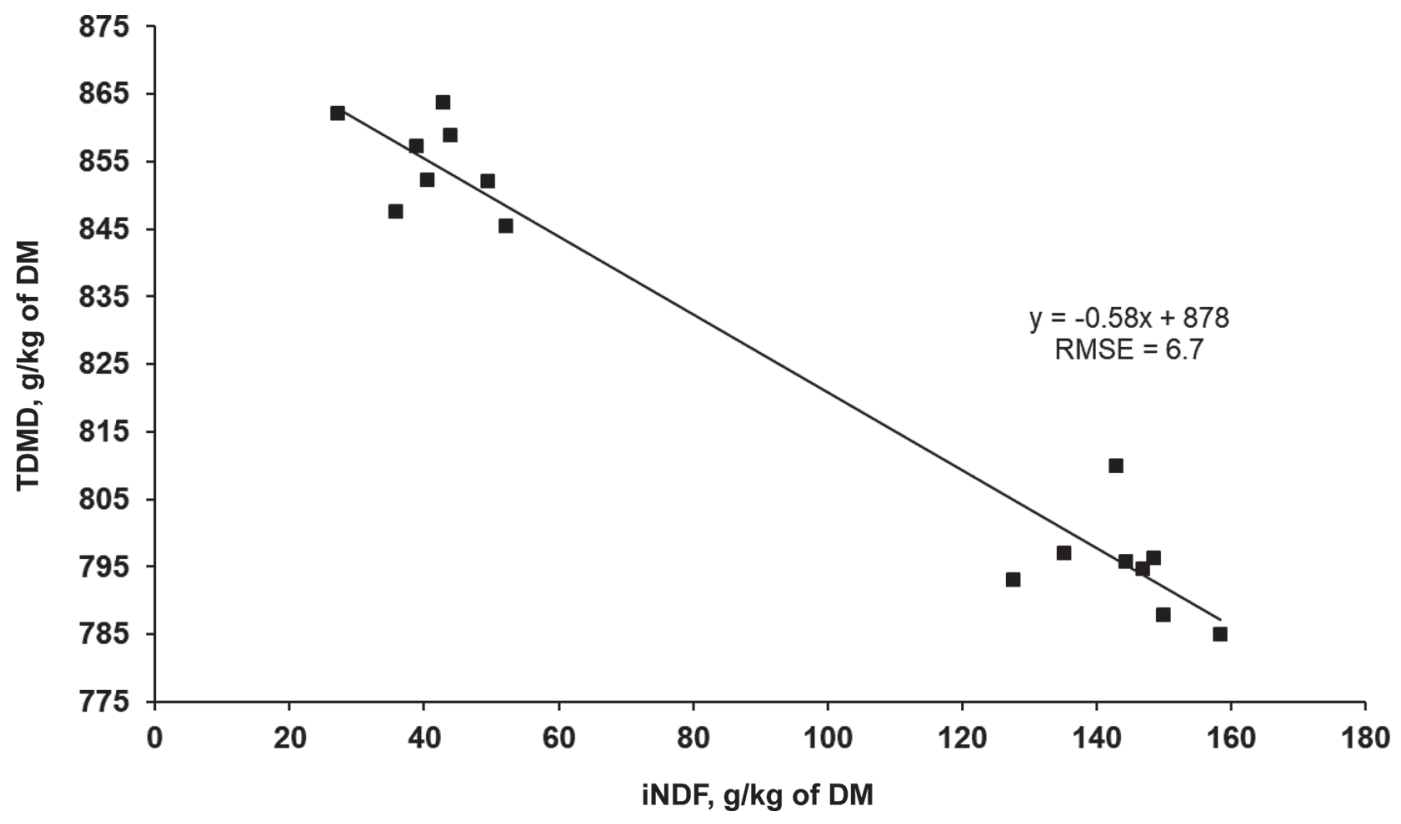

Figure 2. The relationship between true DM digestibility (TDMD) determined in vitro and indigestible NDF (iNDF) concentration of 16 varieties of oats and barley incubated in vitro over $48 \mathrm{~h}$. Observations grouped to the left represent barley varieties, and observations grouped to the right represent oat varieties. RMSE $=$ root mean square error.

tribute to the VFA pool, the higher fat concentration of oats may be an additional factor explaining the lower total VFA production observed for oat-based diets.

\section{Total Gas and Methane Production}

To our knowledge, no study has compared $\mathrm{CH}_{4}$ production between oat- and barley-based diets or between different varieties of the grains in question. The decrease in total gas and predicted in vivo $\mathrm{CH}_{4}$ production we observed for oat- compared with barley-based diets was most likely related to decreased digestibility, because grain species did not affect $\mathrm{CH}_{4}$ production relative to TDMD. In the present study, the silage and percentage of grain inclusion were the same for all treatments, and the differences in total gas and $\mathrm{CH}_{4}$ production between oat- and barley-based diets were most likely related to differences in chemical composition between the grains.

The strong positive relationship $\left(\mathrm{R}^{2}=0.69\right)$ observed between diet TDMD and $\mathrm{CH}_{4}$ production in the present study was also confirmed by other studies (Blaxter and Clapperton, 1965; Ramin and Huhtanen, 2013), and by the fact that $\mathrm{CH}_{4}$ production arises only from the fermentation of digestible matter in the rumen. A better fit between digestible crude nutrients and $\mathrm{CH}_{4}$ production compared with using crude nutrients in the equation was reported by Jentsch et al. (2007). The negative relationship between crude fat concentration in the grains and $\mathrm{CH}_{4}$ production we observed in the present study confirmed the findings of several earlier studies (Czerkawski et al., 1966; Beauchemin et al., 2009; Grainger and Beauchemin, 2011). In the present study, $\mathrm{CH}_{4}$ production decreased by $0.087 \mathrm{~g} / \mathrm{kg}$ of DM when dietary crude fat concentration increased by $1 \mathrm{~g} /$ $\mathrm{kg}$ of DM. However, this response in $\mathrm{CH}_{4}$ production was also influenced by the lower digestibility of oats; as a result, a smaller response in $\mathrm{CH}_{4}$ production to increased dietary fat concentration would be expected. Ramin and Huhtanen (2013) reported a $0.043 \mathrm{~L} / \mathrm{kg}$ of $\mathrm{DM}$ decrease (equal to $0.031 \mathrm{~g} / \mathrm{kg}$ of $\mathrm{DM}$ ) in $\mathrm{CH}_{4}$ production when ether extract was used in the equation and a $0.096 \mathrm{~L} / \mathrm{kg}$ of DM decrease (equal to $0.069 \mathrm{~g} / \mathrm{kg}$ of DM) when ether extract was replaced by fatty acids in the same study.

The $\mathrm{CH}_{4}$-mitigating effect of increased dietary fat concentration may be explained by 3 underlying mechanisms. First, fermentable substrate is replaced with non-fermentable fatty acids (Johnson and Johnson, 1995), decreasing the extent of fermentation and leading to a lower amount of $\mathrm{H}_{2}$ available for methanogenesis. Second, dietary fat suppresses the function of fiber-digesting microbes in the rumen, inducing a shift in fermentation pattern toward propionate production at the expense of acetate and butyrate (McAllister et al., 1996). The propionate-producing pathway captures $\mathrm{H}_{2}$ and acts as an $\mathrm{H}_{2}$ sink in the rumen. However, this was not the case in the present study, because the fermentation pattern was not affected by grain spe- 
cies. In comparison, Vanhatalo et al. (2006) reported a slightly lower proportion of butyrate when barley was replaced by oats in an in vivo study on a grass-silagebased diet. Third, the biohydrogenation of dietary UFA captures $\mathrm{H}_{2}$ and thus acts as another $\mathrm{H}_{2}$ sink in the rumen (Czerkawski et al., 1966). However, the biohydrogenation pathway plays only a minor role in the $\mathrm{CH}_{4}$-mitigating effect of increased dietary fat, because the complete biohydrogenation of $1 \mathrm{~mol}$ of linoleic acid would decreases $\mathrm{CH}_{4}$ production by only $1 \mathrm{~mol}$. Assuming that the fatty acids in oats contain 1.5 double bonds, complete biohydrogenation could decrease $\mathrm{CH}_{4}$ by approximately $0.4 \mathrm{~g} / \mathrm{kg}$ of DM. Therefore, the $\mathrm{CH}_{4}$-mitigating mechanism of increased crude fat concentration in oats is mostly due to the replacement of fermentable substrate by nonfermentable substrate (fatty acids) in the diet, an explanation that is also supported by the decrease in total VFA production in oat- compared with barley-based diets.

In this study, the nonsignificant effects of iNDF and crude fat on $\mathrm{CH}_{4}$ production when they were included in the same model is related to the high correlation between these composition parameters, indicated by a high variance inflation factor (5.9). In addition, the variance inflation factor was relatively high (4.0) between TDMD and crude fat concentration, resulting in a nonsignificant effect of crude fat when included with TDMD in the bivariate model. Due to the collinearity problem between grain composition parameters and digestibility, it was difficult to draw any further conclusions about the relative importance of the $\mathrm{CH}_{4-}$ mitigating mechanisms of oats from this study.

Although oats and barley have additional differences in chemical composition, such as the concentrations of soluble $\beta$-glucans, phenolic compounds, and avenanthramides, these factors did not seem to play a role in the $\mathrm{CH}_{4}$-mitigating effect of oats, because the decrease in $\mathrm{CH}_{4}$ production when replacing barley with oats was as expected based on differences between the grains in terms of digestibility and oil concentration. In addition, the difference between oats and barley in predicted $\mathrm{CH}_{4} \mathrm{VFA}$ values (10\%) was close to the observed difference $(9.8 \%)$ when the $\mathrm{CH}_{4} \mathrm{VFA}$ was compared with observed $\mathrm{CH}_{4}$ endpoint values at $48 \mathrm{~h}$ of incubation. Because the $\mathrm{CH}_{4}$ VFA equation by Wolin (1960) is based on the amount of digestible carbohydrates to predict $\mathrm{CH}_{4}$ production through major VFA molar proportions, the $\mathrm{CH}_{4}$-mitigating effect of oats was accounted for by the decreased digestibility and replacement of fermentable carbohydrates by fat. The mechanistic and empirical $\mathrm{CH}_{4}$ values expressed close relationships to predicted in vivo $\mathrm{CH}_{4}$ production values. The relationships were similar between mechanistic $\mathrm{CH}_{4}$ predictions and predicted in vivo $\mathrm{CH}_{4}$, as well as between empirical $\mathrm{CH}_{4}$ predictions and predicted in vivo $\mathrm{CH}_{4}$. In contrast to our second hypothesis, grain variety did not significantly affect $\mathrm{CH}_{4}$ production, because of relatively small variations in digestibility and oil concentration between different varieties of the 2 grains.

\section{CONCLUSIONS}

Production of $\mathrm{CH}_{4}$ was $8.9 \%$ lower for oat-based diets than for barley-based diets, and in vitro TDMD and total VFA production were also lower for oat-based diets than barley-based diets. The $\mathrm{CH}_{4}$-mitigating effect of oats observed in the present study was most likely related to the lower digestibility and higher oil concentration of oats compared with barley. Based on the results of this experiment, we conclude that replacing barley with oats in a grass-silage-based diet could decrease enteric $\mathrm{CH}_{4}$ production in dairy cows. Differences between grain varieties did not reach statistical significance. The relationships between composition and $\mathrm{CH}_{4}$ production suggest that selecting grain varieties with low iNDF and high fat concentration can reduce $\mathrm{CH}_{4}$ emissions.

\section{ACKNOWLEDGMENTS}

This work was funded by the Swedish Research Council-FORMAS (Sweden) and a scholarship from Raisio Science Foundation (Raisio, Finland). The authors thank the laboratory staff at the Department of Agricultural Research for Northern Sweden in Umeå, Sweden and at the Department of Agricultural Sciences in University of Helsinki, Finland, for their assistance in the laboratory work. In addition, Boreal Plant Breeding Ltd. and Lantmännen are acknowledged for the contribution of seed material.

\section{REFERENCES}

AOAC International. 2012. Official Methods of Analysis. 19th ed. AOAC International, Gaithersburg, MD.

Banaś, A., H. Debski, W. Banaś, W. K. Heneen, A. Dahlqvist, M. Bafor, P. O. Gummeson, S. Marttila, Å. Ekman, A. S. Carlsson, and S. Stymne. 2007. Lipids in grain tissues of oat (Avena sativa): Differences in content, time of deposition, and fatty acid composition. J. Exp. Bot. 58:2463-2470. https://doi.org/10.1093/jxb/erm125.

Beauchemin, K. A., S. M. McGinn, C. Benchaar, and L. Holtshausen. 2009. Crushed sunflower, flax, or canola seeds in lactating dairy cow diets: Effects on methane production, rumen fermentation, and milk production. J. Dairy Sci. 92:2118-2127. https://doi.org/ 10.3168/jds.2008-1903.

Bhatta, R. 2015. Reducing enteric methane emission using plant secondary metabolites. Pages 273-284 in Climate Change Impact on Livestock: Adaptation and Mitigation. V. Sejian, J. Gaughan, L. Baumgard, and C. Prasad, ed. Springer, New Delhi, India. 
Blaxter, K. L., and J. L. Clapperton. 1965. Prediction of the amount of methane produced by ruminants. Br. J. Nutr. 19:511-522. https: //doi.org/10.1079/BJN19650046.

Bryngelsson, S., B. Mannerstedt-Fogelfors, A. Kamal-Eldin, R. Andersson, and L. H. Dimberg. 2002. Lipids and antioxidants in groats and hulls of Swedish oats (Avena sativa L). J. Sci. Food Agric. 82:606-614. https://doi.org/10.1002/jsfa.1084.

Cone, J. W., A. H. Van Gelder, G. J. W. Visscher, and L. Oudshoorn. 1996. Influence of rumen fluid and substrate concentration on fermentation kinetics measured with a fully automated time related gas production apparatus. Anim. Feed Sci. Technol. 61:113-128. https://doi.org/10.1016/0377-8401(96)00950-9.

Czerkawski, J. W., K. L. Blaxter, and F. W. Wainman. 1966. The metabolism of oleic, linoleic and linolenic acids by sheep with reference to their effects on methane production. Br. J. Nutr. 20:349 362. https://doi.org/10.1079/BJN19660035.

Danfær, A., P. Huhtanen, P. Udén, J. Sveinbjörnsson, and H. Volden. 2006. The Nordic dairy cow model, Karoline - Description. Pages 383-406 in Nutrient Digestion and Utilization in Farm Animals: Modelling Approaches. E. Kebreab, J. Dijkstra, A. Bannink, W. J. J. Gerrits, and J. France, ed. CABI Publishing, Boston, MA.

Danielsson, R., M. Ramin, J. Bertilsson, P. Lund, and P. Huhtanen. 2017. Evaluation of a gas in vitro system for predicting methane production in vivo. J. Dairy Sci. 100:8881-8894. https://doi.org/ $10.3168 /$ jds.2017-12675.

Ekern, A., Ø. Havrevoll, A. Haug, J. Berg, P. Lindstad, and S. Skeie. 2003. Oat and barley based concentrate supplements for dairy cows. Acta Agric. Scand. A Anim. Sci. 53:65-73. https://doi.org/ 10.1080/09064700310012476.

Ericson, B., and J. André. 2010. HPLC-Applications for agricultural and animal science. Pages $23-26$ in Proc. 1st Nordic Feed Sci. Conf., Uppsala Sweden. Swedish University of Agricultural Sciences, Uppsala, Sweden.

Evers, T., and S. Millar. 2002. Cereal grain structure and development: Some implications for quality. J. Cereal Sci. 36:261-284. https:// doi.org/10.1006/jcrs.2002.0435.

FAO (Food and Agriculture Organization of the United Nations). 2006. World agriculture: Towards 2030/2050. Interim report. Food and Agriculture Organization of the United Nations, Rome, Italy. Accessed Mar. 30, 2019. http://www.fao.org/fileadmin/user_upload/ esag/docs/Interim_report_AT2050web.pdf.

Grainger, C., and K. A. Beauchemin. 2011. Can enteric methane emissions from ruminants be lowered without lowering their production? Anim. Feed Sci. Technol. 166-167:308-320. https://doi.org/ 10.1016/j.anifeedsci.2011.04.021.

Guan, H., K. M. Wittenberg, K. H. Ominski, and D. O. Krause. 2006. Efficacy of ionophores in cattle diets for mitigation of enteric methane. J. Anim. Sci. 84:1896-1906. https://doi.org/10.2527/jas .2005-652.

Holtekjølen, A. K., A. K. Uhlen, E. Bråthen, S. Sahlstrøm, and S. H. Knutsen. 2006. Contents of starch and non-starch polysaccharides in barley varieties of different origin. Food Chem. 94:348-358. https://doi.org/10.1016/j.foodchem.2004.11.022.

Hristov, A. N., J. Oh, J. L. Firkins, J. Dijkstra, E. Kebreab, G. Waghorn, H. P. S. Makkar, A. T. Adesogan, W. Yang, C. Lee, P. J. Gerber, B. Henderson, and J. M. Tricarico. 2013. Special topicsMitigation of methane and nitrous oxide emissions from animal operations: I. A review of enteric methane mitigation options. J. Anim. Sci. 91:5045-5069. https://doi.org/10.2527/jas.2013-6583.

Hristov, A. N., J. Oh, F. Giallongo, T. W. Frederick, M. T. Harper, H. L. Weeks, A. F. Branco, P. J. Moate, M. H. Deighton, S. R. O. Williams, M. Kindermann, and S. Duval. 2015. An inhibitor persistently decreased enteric methane emission from dairy cows with no negative effect on milk production. Proc. Natl. Acad. Sci. USA 112:10663-10668. https://doi.org/10.1073/pnas.1504124112.

Huhtanen, P., M. Ramin, and P. Udén. 2015. Nordic dairy cow model Karoline in predicting methane emissions: 1. Model description and sensitivity analysis. Livest. Sci. 178:71-80. https://doi.org/10 .1016/j.livsci.2015.05.009.
Huhtanen, P., A. Seppälä, M. Ots, S. Ahvenjärvi, and M. Rinne. 2008. In vitro gas production profiles to estimate extent and effective first-order rate of neutral detergent fiber digestion in the rumen. J. Anim. Sci. 86:651-659. https://doi.org/10.2527/jas.2007-0246.

IPCC (Intergovernmental Panel of Climate Change). 2014. Mitigation of climate change. Contribution of Working Group III to the Fifth Assessment Report of Intergovernmental Panel on Climate Change. Chapter 1. Accessed Dec. 19, 2018. https://www.ipcc.ch/ report/ar5/wg3/.

Jentsch, W., M. Schweigel, F. Weissbach, H. Scholze, W. Pitroff, and M. Derno. 2007. Methane production in cattle calculated by the nutrient composition of the diet. Arch. Anim. Nutr. 61:10-19. https://doi.org/10.1080/17450390601106580.

Johnson, K. A., and D. E. Johnson. 1995. Methane emissions from cattle. J. Anim. Sci. 73:2483-2492. https://doi.org/10.2527/1995 $.7382483 \mathrm{x}$.

Krizsan, S. J., M. Rinne, L. Nyholm, and P. Huhtanen. 2015. New recommendations for the ruminal in situ determination of indigestible neutral detergent fibre. Anim. Feed Sci. Technol. 205:31-41. https: //doi.org/10.1016/j.anifeedsci.2015.04.008.

Lee, C. J., R. D. Horsley, F. A. Manthey, and P. B. Schwarz. 1997. Comparisons of $\beta$-glucan content of barley and oat. Cereal Chem. 74:571-575. https://doi.org/10.1094/CCHEM.1997.74.5.571.

LUKE. 2019. Finnish feed tables. Accessed Jan. 13, 2019. https:// portal.mtt.fi/portal/page/portal/Rehutaulukot/feed_tables _english.

Martin, C., J. Rouel, J. P. Jouany, M. Doreau, and Y. Chilliard. 2008. Methane output and diet digestibility in response to feeding dairy cows crude linseed, extruded linseed, or linseed oil. J. Anim. Sci. 86:2642-2650. https://doi.org/10.2527/jas.2007-0774.

Martin, P. A., and P. C. Thomas. 1988. Dietary manipulation of the yield and composition of milk: Effects of dietary inclusions of barley and oats in untreated or formaldehyde-treated forms on milk fatty acid composition. J. Sci. Food Agric. 43:145-154. https://doi .org/10.1002/jsfa.2740430205.

McAllister, T. A., K. J. Cheng, E. K. Okine, and G. W. Mathison. 1996. Dietary, environmental and microbiological aspects of methane production in ruminants. Can. J. Anim. Sci. 76:231-243. https: //doi.org/10.4141/cjas96-035.

Menke, K. H. 1988. Estimation of the energetic feed value obtained from chemical analysis and in vitro gas production using rumen fluid. Anim. Res. Dev. 28:7-55.

NRC (National Research Council). 2001. Nutrient Requirements of Dairy Cattle. 7th rev. ed. Natl. Acad. Press, Washington, DC.

Peterson, D. M. 2001. Oat antioxidants. J. Cereal Sci. 33:115-129. https://doi.org/10.1006/jcrs.2000.0349.

Puhakka, L., S. Jaakkola, I. Simpura, T. Kokkonen, and A. Vanhatalo. 2016. Effects of replacing rapeseed meal with fava bean at 2 concentrate crude protein levels on feed intake, nutrient digestion, and milk production in cows fed grass silage-based diets. J. Dairy Sci. 99:7993-8006. https://doi.org/10.3168/jds.2016-10925.

Ramin, M., and P. Huhtanen. 2012. Development of an in vitro method for determination of methane production kinetics using a fully automated in vitro gas system - A modelling approach. Anim. Feed Sci. Technol. 174:190-200. https://doi.org/10.1016/j .anifeedsci.2012.03.008.

Ramin, M., and P. Huhtanen. 2013. Development of equations for predicting methane emissions from ruminants. J. Dairy Sci. 96:24762493. https://doi.org/10.3168/jds.2012-6095.

Sayer, S., and P. J. White. 2011. Oat starch: Physicochemical properties and function. Pages 109-122 in Oats: Chemistry and Technology. 2nd ed. F. H. Webster and P. J. Wood, ed. AACC International. Saint Paul, MN.

Schofield, P., R. E. Pitt, and A. N. Pell. 1994. Kinetics of fiber digestion from in vitro gas production. J. Anim. Sci. 72:2980-2991. https://doi.org/10.2527/1994.72112980x.

Tylutki, T. P., D. G. Fox, V. M. Durbal, L. O. Tedeschi, J. B. Russell, M. E. Van Amburgh, T. R. Overton, L. E. Chase, and A. N. Pell. 2008. Cornell Net Carbohydrate and Protein System: A model for 
precision feeding of dairy cattle. Anim. Feed Sci. Technol. 143:174202. https://doi.org/10.1016/j.anifeedsci.2007.05.010.

Van Soest, P. J., J. B. Robertson, and B. A. Lewis. 1991. Methods for dietary fiber, neutral detergent fiber and non-starch polysaccharides in relation to animal nutrition. J. Dairy Sci. 74:3583-3597. https://doi.org/10.3168/jds.S0022-0302(91)78551-2.

van Zijderveld, S. M., W. J. J. Gerrits, J. Dijkstra, J. R. Newbold, R. B. A. Hulshof, and H. B. Perdok. 2011. Persistency of methane mitigation by dietary nitrate supplementation in dairy cows. J. Dairy Sci. 94:4028-4038. https://doi.org/10.3168/jds.2011-4236.

Vanhatalo, A., T. Gäddnäs, and T. Heikkilä. 2006. Microbial protein synthesis, digestion and lactation responses of cows to grass or grass-red clover silage diet supplemented with barley or oats. Agric. Food Sci. 15:252-267. https://doi.org/10.2137/ 145960606779216236 .

Volden, H. 2011. NorFor-The Nordic Feed Evaluation System. Wageningen Acad. Publ., Wageningen, the Netherlands.

Welch, R. W. 1978. Genotypic variation in oil and protein in barley grain. J. Sci. Food Agric. 29:953-958. https://doi.org/10.1002/jsfa .2740291109 .

Welch, R. W., and J. M. McConnell. 2001. Oats. Pages 367-390 in Cereals and Cereal Products: Chemistry and Technology. D. A.
V. Dendy and B. J. Dobraszczyk, ed. Aspen Publishers, Gaithersburg, MD.

Wolin, M. J. 1960. A theoretical rumen fermentation balance. J. Dairy Sci. 43:1452-1459. https://doi.org/10.3168/jds.S0022 -0302(60)90348-9.

Yan, T., R. E. Agnew, F. J. Gordon, and M. G. Porter. 2000. Prediction of methane energy output in dairy and beef cattle offered grass silage-based diets. Livest. Prod. Sci. 64:253-263. https://doi .org/10.1016/S0301-6226(99)00145-1.

Zhou, M., K. Robards, M. Glennie-Holmes, and S. Helliwell. 1999. Oat lipids. J. Am. Oil Chem. Soc. 76:159-169. https://doi.org/10 .1007/s11746-999-0213-1.

\section{ORCIDS}

M. Ramin (® https://orcid.org/0000-0002-0028-896X

S. Jaakkola @ https://orcid.org/0000-0002-0986-1590

A. Grimberg (1) https://orcid.org/0000-0002-3083-7448

A. S. Carlsson (1) https://orcid.org/0000-0002-8525-9753

P. Huhtanen (1) https://orcid.org/0000-0001-7855-7448 